\title{
Model Implementation of Tourism Development Policies on Oetune Beach, South Central Timor District
}

\author{
Hans Arisandy Lao*, Enos Kabu, Hamzah Nasarudin \\ Politeknik Negeri Kupang \\ Kupang, Indonesia \\ *hanslao@pnk.ac.id, Ino.william@yahoo.co.id, alhimza@gmail.com
}

\begin{abstract}
South Central Timor Regency is one of the districts in East Nusa Tenggara Province which has many natural potentials that can be developed. One of its natural potentials is marine tourism, where existing marine tourism can be empowered by the government to increase real income. The research method uses a qualitative approach. The data sources used are primary and secondary data. Data collection techniques in this study were carried out through interviews, observation and documentation. The data analysis was conducted in a descriptive qualitative manner using the Miles and Huberman analysis model. This study seeks to find the ideal tourism policy implementation formulation as the object of Oetune beach tourism by basing on four dimensions of public policy which are often referred to as the Edwar III model, consisting of communication, resources, executive attitudes and bureaucratic structures.
\end{abstract}

\section{Keywords-implementation of policy and tourism}

\section{BACKGROUND}

Indonesia is a country that is very beautiful and rich in nature and culture. All of that can be used by the people of Indonesia as an object and tourist attraction that can attract tourist visits. Tourists who come to visit are a source of foreign exchange that can increase state and community income in the location of the object tourism [1]. To achieve the above, the central government adopted a policy known as regional autonomy, this is regulated in the regional autonomy law which consists of Law No. 32 of 2004, Concerning Regional Government and Law no. 25 of 1999, Concerning Central and Regional Financial Balance, that regions are given the right and authority to regulate and administer their respective regions according to the potential that the regions have to develop, as a consequence of the implementation of regional autonomy. For this reason, regional governments are expected to have the ability identify and manage the potentials that exist in the area, to be used effectively and efficiently for the implementation of development activities in order to improve the quality of life of the community and the region. Thus the local government is obliged to consistently manage the potentials that can be developed, one of which is the development and management of the tourism sector, which is expected to increase regional income and improve the welfare of the community, nation and state.

So the development of tourism is essentially a part of national development efforts to realize physical and mental well-being for all Indonesian people, so that the wealth of the archipelago as the capital and foundation for the development of the nation's culture as a whole can be observed by the community. With a good development of a tourist location, it is hoped that there will be an increase in the number of tourists, both local and foreign, which in turn will increase the level of livelihood of the local community.

\section{LITERATURE REVIEW}

\section{A. Policy Implementation}

Policy implementation is the stage of implementing decisions between the formation of a policy, such as only articles of a legislative law, the issuance of an executive regulation and the issuance of a court decision or the issuance of regulatory standards and the consequences of policies for society that affect several aspects of their life.

\section{B. Policy}

According to Sombu et al. [2], policy is a series of concepts and ideas that form the outline and basis of plans for the implementation of a job, leadership, and how to act in government, organizations, and so on; statement of ideals, goals, principles, or intent as a guideline, as an effort to achieve the expected goals.

\section{Public Policy Dimension}

Edwar III's model, in Tahir [3] suggests that in the policy implementation study approach the abstract question starts from what are the pre-conditions for the success of public policy and second is what are the main obstacles to public policy success. Then it was also emphasized, to answer 
this important question, Edwar III offered four factors in implementing public policies, namely:

- Communication;

- Resource;

- The attitude of the executor;

- Bureaucratic structure.

\section{Definition of Tourism}

According to Spillane [4] defines tourism as a journey from one place to another, temporary, carried out individually or in groups, as an effort to find balance / harmony and happiness with the environment in the social, cultural, natural and scientific dimensions. Meanwhile, Pendit [5] defines tourism as a process of temporary departure from someone or more to another place outside his residence. The incentives for his departure are due to various interests, whether due to economic, social, cultural, political, religious, health or other interests such as because just want to know, add experience or to learn.

\section{E. Tourism and Regional Economy}

The regional autonomy policy gives wider authority and flexibility to districts / cities in exploring and developing regional potential. This is evident from the fact that many autonomous regions are creative and take the initiative in ways to advance their regions, for example, among others: various methods are used to increase locally-generated revenue, encourage the rate of planting capital through promotion and improvement of licensing services, build and improve the quality of infrastructure to support investment activities, develop potential production centers, carry out various development management innovations and improve the quality of human resources. Thus there are two aspects that need attention, namely local economic development and partnerships. Attention to tourism has spread very smoothly because it is aware of the benefits it brings to tourist-receiving countries:

- That tourism is a source of foreign exchange income by selling services and goods related to tourism. That this income flows quickly and is directly divided widely into tourism in the national economy, so as to be able to divide the rate of income widely, multiply and circulate to all layers of wholesalers and retailers, transportation, various components of the tourism sector, needs and businesses based on the level of consumer spending

- Whereas tourism is a continuation market in line with the rapid increase in the level of family income which is not used up, especially in countries with advanced industries. especially in countries with advanced industries.
- Whereas the tourism industry, when compared to other industries, includes industries whose capital investment is small in proportion to the possible income streams.

- That tourism provides an export market where consumers come to research these products.

- Whereas the products being sold are mainly in the form of services and cannot be touched because of the cool air, beautiful nature, there are places where the potential is endless, and are only subject to limited promotional and sales efforts.

\section{RESEARCH METHODS}

\section{A. Design Research}

This research is a qualitative descriptive study, according to Sudjarwo [6]. This method is a method used to get a correct picture of an object of research.

\section{B. Research Sites}

This research was conducted at the Culture and Tourism Office of Timor Tengah Selatan Regency, located in the city of Soe (NTT). In addition, this research was also carried out at Oetune beach.

The subjects of this research are the main informants of the Head of the Office of Culture and Tourism of the South Central Timor Regency, the tourism office officers on the Oetune beach, tourists, the community (residents) who live around tourist objects on the Oetune beach.

\section{Data Analysis Method}

In data analysis, an interactive analysis model was carried out [7], in this analysis the 3 components of the analysis are (figure 1).

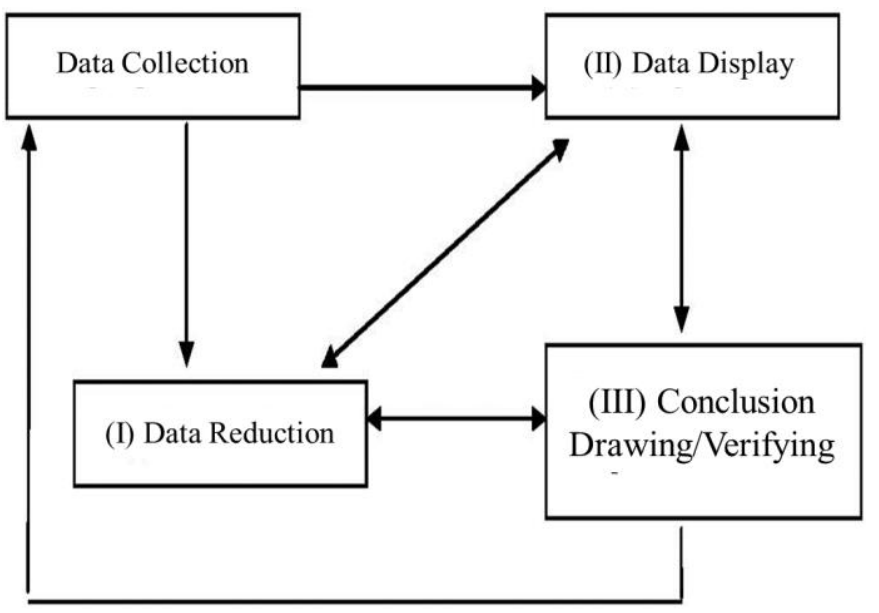

Fig. 1. Interactive analysis model of Miles and Huberman. 
The steps that must be taken in analyzing data:

1) Data reduction: Data reduction activities to summarize field notes by sorting out the main things related to research problems.

2) Presentation of data: The presentation of qualitative research data is: the process of finding and $\mathrm{m}$, systematically arranging data obtained from interviews, field notes and other materials so that they are easy to understand and can be informed to others [8].

\section{RESULTS AND DISCUSSION}

\section{A. Local Government Policies in Managing Oetune Beach Attractions}

Law 23/2014 on regional government explains that what is meant by regional government is the administration of government affairs by the regional government and the DPRD according to the principle of autonomy and co-administration with the broadest principle of autonomy, with the aim of accelerating the realization of community welfare. This is one of the main tasks of the South Central Timor regional government which manages the Oetune beach tourism object. The role of local government in managing this Oetune beach tourism object includes planning, implementation and supervision.

\section{B. Local Government Policies in Tourism Management at the Planning Stage}

Policies are actually patterned actions that lead to certain agreed goals and are not just random decisions to do something. This means that the government in making a policy is not only for its personal interests, but based on the interests of the community. Through government policy, it wants to make arrangements in society to achieve the vision of the government itself while still prioritizing the interests of the people. Resolving problems that occur in society so that community participation in implementing such policies can accelerate with development in the regions. The government in making a policy must be able to take an action which is a form of allocating the values of the community itself.

\section{Local Government Policies in Tourism Management at the Socialization Stage}

1) Dissemination of Regional Regulation number 21 of 2011: The initial step for the role of the Regional Government at the socialization stage is to conduct socialization related to the Regent Regulation number 21 of 2011 concerning tourism objects. This socialization stage is important because it is the initial stage for the Regional Government, namely the South Central Timor Regency Tourism and Culture Office in managing tourism and improving tourism infrastructure on the oetune beach.

2) Socialization about Tourism Awareness Groups: In the socialization stage with Tourism Awareness Group the form is as coaching, the targets of Tourism Awareness Group coaching include, increasing the capacity of Tourism Awareness Group and the quality of their role in supporting tourism development efforts on the oetune coast, the growth of Tourism Awareness Group on the oetune beach which can work together with related stakeholders in supporting tourism development, and the creation of an adequate database on Tourism Awareness Group as a basis for program planning in the development and empowerment of Tourism Awareness Group in supporting tourism development.

\section{Local Government Policies in Tourism Management at the Implementation Stage}

1) Forming a Tourism Awareness Group: In managing tourism potential, of course, the government does not walk alone. There needs to be support from the private sector and the community to accelerate the achievement of these tourism development goals and optimize the results of the tourism management. In managing the Oetune beach initially the manager has formed a Tourism Awareness Group to carry out sales at the location of the Oetune beach tourism object which consists of 12 sellers but over time the number of members of the tourism conscious group who are still selling on Oetune Beach is 3 people to meet the needs of tourists visiting Oetune Beach.

2) Physical development: In the framework of developing Oetune Beach as one of the tourist destinations in South Central Timor Regency to fulfill criteria which include attractiveness, road access, facilities for tourists, friendliness of the surrounding population, and being healthy, as a tourist destination, the Tourism and Culture Office is holding physical development to meet the criteria. This is in the form of the construction of several supporting facilities in the Oetune beach area, including Lopo totaling 18 units consisting of 3 units made of local materials, while the other 15 units use nonlocal materials. 4 units of Gazebo, 1 unit of business outlets with 4 business doors, and making a viewing tower 12 meters high.

In addition, it also provides 3 units of villas, as well as providing prayer houses that are used for all religions, building keliliang fences at tourist objects as well as guard posts and houses for duty officers, and providing facilities such as beds and trash cans to maintain cleanliness and order in oetune beach tourist attractions.

\section{E. Local Government Policies in Tourism Management at the Supervision Stage}

In the management of tourism, Oetune Beach is supervised by 3 officers on duty and one coordinator who is in charge of recording and collecting fees which are then reported to the Culture and Tourism Office of the South Central Timor Regency. This is done to develop and manage the tourism potential of Oetune Beach. 
To measure the progress of tourism in South Central Timor, one of which is by visiting tourists, once every three months the South Central Timor Regency Tourism and Culture Office conducts monitoring, one of which is to record the number of tourists there. Based on data from tourism visits, the South Central Timor Regency Tourism and Culture Office monitors or monitors the development of Oetune Beach tourism.

\section{F. Regional Government Constraints in Oetune Tourism Management, Tuafunu Village, Kualin District, South Central Timor Regency}

In managing the tourism potential of Oetune Beach, it will not run smoothly. The government encountered various obstacles that hindered the development of the Oetune beach tourism. The obstacles encountered by the government in the process of managing Oetuna coastal tourism are as follows:

1) Poor road infrastructure: Oetune Beach tourist attractions offer such beautiful views. Nature lovers and even ordinary tourists will definitely be interested in enjoying the beautiful scenery of Oetune Beach. Because from Oetune beach, tourists will be treated to views in the form of sunset, sunrise, and sand dunes that resemble very beautiful and very beautiful gurundan. However, the beautiful scenery on this beach is not supported by adequate road conditions. This can be seen from the number of roads that are damaged at several points, especially before entering the beach location, as well as the narrow roads which are quite difficult when car drivers pass each other.

2) The lack of adequate supporting facilities: Oetune beach does not yet have a process of providing adequate clean water to meet the needs of visitors so that sometimes there is a shortage of clean water in the cleanliness facilities, as well as the placement of garbage bins that are not sufficient for the entire area of this tourist attraction.

Facilities have not been prepared to allow visitors to enjoy the joy of the Oetune sea so that visitors only take advantage of it the time is above the mainland oetune, if it is managed properly it should be able to increase local revenue. Not yet established cooperation with private parties Regional autonomy has opened up opportunities for local governments to develop local policies wisely. However, sometimes implementing a policy or implementing a development plan has not been maximally implemented because the existence of new autonomous regions is not accompanied by adequate human and financial capacity. Thus there are still many delays in development including in the development of tourism in the Oetune Beach area. Therefore, local governments need to find solutions to these problems by involving various stakeholders in the implementation of development, for example the private sector. Likewise, in the management of the Oetune Beach area, it is still hampered by a lack of funds, because the government still has not fully involved the private sector in the process of developing the Oetune Beach tourist area.

3) Low human resources in the Oetune Beach tourism management process: Managerial is a component needed in all fields including tourism. Good management in promotional, planning, marketing and tourism development activities will greatly influence the success of efforts to increase visitor flow. So that in tourism management, human resources who are truly competent in their fields are needed to improve tourism management in the Oetune Beach area. However, HR in Tuafunu Village in managing Oetune Beach can be said to be very low, this is due to the lack of quantity and quality of the surrounding community who are responsible for managing tourist attractions.

\section{CONCLUSION}

The management and development of Oetune Beach in Timor Tengah Selatan Regency is developed in accordance with government policies contained in regional regulation no. 21 of 2011 concerning recreation and sports areas. This has been proven by the inclusion of the tourism sector as a priority for regional government development and the formation of a tourism awareness group for Oetune Beach. This tourism awareness group is fostered through guidance carried out by the Tourism and Culture Office both formally and informally to develop, maintain and preserve tourist objects around their residence.

\section{REFERENCES}

[1] I.G. Pitana and P.G. Gayatri, Sosiologi Pariwisata. Yogyakarta: CV Andi Offset, 2005

[2] T. Sombu, M.E. Kalola, E.R. Palandeng, dan J. Lumolos, Kamus Umum Politik dan Hukum. Bandung: Jala Pramata Aksara, 2010.

[3] A. Tahir, Kebijakan Publik danTransparansi Penyelanggaraan Pemerintah Daerah. Bandung: CV Alfabeta, 2014.

[4] J.J. Spillane, Ekonomi Pariwisata Sejarah dan Prospeknya. Yogyakarta: Kanisius, 1987

[5] N.S. Pendit, Ilmu Pariwisata Sebuah Pengantar Perdana, edisi revisi. Jakarta: PT. Pradnya Pramita, 1994.

[6] Sudjarwo, Metodologi Penelitian Sosial. Bandung: Mandar Maju, 2001

[7] Sutopo, Metode penelitian. Yogyakarta: Andi Offset, 2006.

[8] Sugiyono, Metode penelitian pendidikan: (pendekatan kuantitatif, kualitatif dan R \& D). Bandung: Alfabeta, 2007. 